\title{
THE RESEARCH 1 UNIVERSITY: STRATEGIES AND PUBLIC AGENDA
}

\author{
Robert E. Barnhill \\ Vice Chancellor for Research \& Public Service \\ University of Kansas
}

\section{Prologue: Research Competitiveness}

I would like to tie together several strands in this presentation on Strategies and Public Agenda for the Research 1 University. With his keynote address today, George Walker set us on a good course to discuss the meeting's topic, "Making Research Part of the Public Agenda."

First, I would like to cite the principal conclusion from a conference on Research Competitiveness. In April 1995, the American Association for the Advancement of Science (AAAS) convened some forty people at Kiawah Island, South Carolina. Included were experts in research policy such as Roger Geiger, Irwin Feller, Susan Cozzens, and Harry Lambright. The purpose of the meeting was to help EPSCoR states become more competitive in research. The AAAS invited two "outliers," that is, two people who had been successful in non-EPSCoR states, to pass around their secrets of success. Those two people were George Walker from Indiana University and me, representing Arizona State University. This was my first meeting with George and also with the national research policy experts. Along with my institutions, Arizona State University (ASU) and the University of Kansas (KU), I personally have subsequently profited from meeting George and the other research policy gurus.

We prepared manuscripts prior to the 1995 meeting which then became a published book (see references). Roger Geiger's pre-meeting manuscript described the overall research scene, focusing on federal expenditures. He mentioned that only five universities had made a considerable improvement in research competitiveness in the 1980's and early 1990's: ASU was one of the five. Geiger went on to say, "Presidential backing for strengthening research is a virtual prerequisite. In some cases, presidents have identified themselves with ambitious research goals; in others, presidents have more quietly backed the efforts of provosts or vice presidents of research (ASU)." Geiger also said, "An institutional commitment to research almost presupposes the organization of research administration under a single office. The office of the vice president for research does far more than standardize research accounting and offer administration support. It should become the initiator of and advocate for proactive policies." 
After three days, the conferees agreed on one fundamental principle: Leadership at every level is essential for institutional research competitiveness. This includes leadership not only at the president/chancellor level, but also within the faculty and the rest of the university research community.

\section{Prior Merrill Center Research Policy Meetings}

Let me review for you the last three Merrill Center conferences on research policy.

Dobilizing for Research Opportunities in the Next Century (1998)

$>$ Building Cross-University Alliances that Enhance Research (1999)

> Making Research Part of the Public Agenda (2000)

The keynote speakers have been Michael Crow, Columbia University, Luis Proenza, University of Akron, and George Walker, Indiana University, respectively. Michael Crow, now the Executive Vice Provost at Columbia, explained the "niche" strategy whereby a university emphasizes a few areas of institutional expertise. Luis Proenza, formerly Vice President for Research at Purdue University and now President of the University of Akron, discussed "strategic intent" and its ramifications in collaborative efforts. George Walker, Vice President for Research and Graduate School Dean at Indiana University, discussed today the Indiana story of mobilizing "the public" to support research. I will take up each of these three themes in turn.

\section{Setting the Stage for Success}

The dawn of the new millennium is an exciting time for research in general and science in particular. It is an excellent time for organizations to take stock of their goals and resources, and their impact.

Universities have great stability and a long and honorable history. But it is important that institutions be able to move as quickly as possible. Each university must answer these questions:

$>$ Can we remain relevant in today's fast moving world? Or will we be relegated to a genteel backwater role in American society?

If we wish to remain, or become, relevant, how can we do it? What are reasonable goals and how can we achieve them? 
Michael Crow estimates that in the near future there will be about 75 significant research universities in the United States. These select universities will obtain almost all the competitive federal funding.

Andrew Grove, CEO of Intel Corporation, has written the book, Only the Paranoid Survive, to which I will return in a few minutes. Let me paraphrase the book's title to: Only the Flexible Will Thrive. Only universities that are flexible in their approach and have clear goals and expectations will do well, or even have the chance of being among Crow's 75 universities.

At the 1999 Merrill conference, Luis Proenza introduced the key concept of "strategic intent," as examined in the book Competing for the Future. Strategic intent has the attributes of direction, discovery and destiny.

D Direction: "Most companies are over-managed and under-led." That is, "more effort goes into the exercise of control than into the provision of direction."

D Discovery: "Strategic intent should offer employees the enticing spectacle of a new destination or at least new routes to well-known destinations."

> Destiny: "Only extraordinary goals provoke extraordinary efforts." Thus, numerical goals are less energizing to employees (or researchers) than goals such as being "the best" in defined competitive areas.

Strategic intent goes beyond strategic planning. Strategic planning is a "feasibility sieve." Strategic intent goes beyond the feasible to what is barely possible, e.g., President Kennedy's vision of a space landing on the moon.

\section{Successful Examples}

Let me take you through three examples of strategic intent applied to public universities.

1. Arizona became a state, the forty-eighth, in 1912. It still feels like a frontier. A few of you know that I spent 11 pleasant years at Arizona State University. I want to discuss the example of the friendly rival down the road, the University of Arizona. From Roger Geiger's book, Research and Relevant Knowledge, "the same factors that have been identified in the advancement of other research universities - establishing centers of research excellence, 
academic leadership, and the availability of resources - were vital to Arizona as well." In 1959, President Richard A. Harvill stated that "Arizona's role in the expanding research economy would be to concentrate on fields in which it possessed some natural advantage." (Clark Kerr has also used this phrase "natural advantages.") At the time, just after Sputnik in 1957, the University of Arizona had only $\$ 1$ million in federal funding and no nationally recognized departments. In the years that followed, two centers emerged, one in astronomy and one in anthropology. Each relied on natural advantages: astronomy on clear skies and nearby mountains for observatories; and anthropology on the presence of a large number of Native American tribal nations. (There are 21 tribal nations in the state.) In 1966, the corresponding two departments became the first University of Arizona departments to receive national recognition in reputational rankings.

Geiger discerns a pattern to establishing these university centers of research excellence:

$>$ a natural advantage

$>$ topics a little off the beaten academic path

$>$ areas of excellence that have far-reaching effects on the rest of the university

Note especially Geiger's third point: "achieving these pockets of research excellence... overcame a kind of defeatist attitude that was prevalent on the campus."

2. Before going to ASU, I spent 22 years at the University of Utah, in Salt Lake City. Technology sectors in Salt Lake City account for some $\$ 10$ billion in annual revenues and five of the six key factors in the city's development as a technology center hinge on the University of Utah. One spin-off companyDEvans \& Sutherland Corporation $\nabla$ has helped created more than 150 computer and software companies. In 1965, David Evans came to the University of Utah to chair the Computer Science Department. In the 1970's, he brought Ivan Sutherland to the University of Utah with the strategic intent of forming the premiere computer graphics group in the country. Evans and Sutherland formed their company in the university's new research park. (Many of my own students in mathematics worked for the new company.) The University of Utah Research Park was itself a product of strategic intent. Wayne Brown, Dean of Engineering, worked with President David Gardner to inaugurate the Research Park. Their strategic intent was to develop a place where local entrepreneurship and expertise could flower. Evans \& Sutherland became the anchor tenant of the new 
park. The three elements of direction, discovery and destiny prevailed for all of these people relative to their respective goals.

3. I now turn to a more recent example, Arizona State University, where I served from 1986-1997. ASU is a large university in Phoenix, a metropolitan area with considerable high tech industry. However, ASU only formally adopted a research mission in 1980. At about the same time, C. Roland Haden, the new Dean of Engineering, met with local business people who wanted ASU to become a significant research university. Their goal was to stimulate economic development. "Engineering Excellence" was born from these meetings and sold to Governor Bruce Babbitt and other political and business leaders. Unlike many universities in the early 1980's, ASU was growing and thus received new science faculty positions to which excellent people were hired. This combination of Engineering Excellence and the emphasis on hiring scientists lifted the entire university (cf. Geiger's remarks above). At ASU, I served for five years as Chair of Computer Science and Engineering and thus worked within Engineering Excellence on the front lines. I then served for six years as the University's second Vice President for Research. During that time, ASU's external funding doubled and, in 1994, ASU became a Research 1 university for the first time in its history.

Strategic intent by top leadership, coupled with natural advantages and local expertise, can lead to research enhancement that lifts the entire institution. Lifting the entire institution is a phenomenon that occurred at all three of the universities I mentioned—when all the elements were in place.

\section{Action Agenda}

Only the Paranoid Survive, written by Andy Grove of Intel, contains useful advice. As I said earlier, for use in our discussions about universities, I've modified the title of his book to Only the Flexible Will Thrive. Grove discusses "strategic inflection points," which demarcate times of strategic changes in the performance of a company. These changes can be either positive or negative.

Positive strategic inflection points are reached more often if we apply strategic intent to our universities. Having goals that reflect our institutional missions can affect major changes in the output of our university research communities. In relation to this thought is the important topic of academic performance measures. 


\section{Performance Measures}

Performance metrics are important because we will become what we measure. Thus we should select and promote measures that reflect values we think are important.

As an aside, several senior research officers of public universities are currently studying research and graduate education performance measures as part of our work for the Council on Research Policy and Graduate Education of the National Association of State Universities and Land Grant Colleges. The work is ongoing, and we believe it will have national significance. George Walker and I have both played leading roles in this work and would be glad to discuss it with you during the discussion session.

A "road map" can be a useful guide. By "road map" I mean a well thought out formal "action agenda" document. This concept is adopted from the Japanese semi-conductor industry where it has been used since the early 1980's when Japan became a threat to American dominance in that field.

Universities often do not set research goals or, if they do, the goals don't have quantitative measures. My counsel is to encourage setting goals that are both ambitious and multidimensional.

Performance measures are used to rank and rate universities nationally, as well as to provide accountability locally. Well-known rankings are published by U.S. News and World Report, the National Research Council on graduate education, the Carnegie Foundation and in the book by Graham and Diamond, The Rise of American Research Universities. The statistics collected by the National Science Foundation ("NSF numbers") provide rankings based on both federal research expenditures and on all research expenditures. There are recent studies by The Center at the University of Florida and by the Association of American Universities that use multiple dimensions of quantitative measurements.

If we would like to enlist our citizens' support of research, it is essential to have quantitative goals that are easily understandable by the public. This is another important reason for performance measures.

Tactics: Intra- and Inter-institutional

The University of Kansas provides an interesting case study for us today. When I returned to my alma mater in 1997, KU had reached a research equilibrium, wherein its national research ranking was fairly static 
and at the institutional level little change had occurred within memory. State support of the university had apparently been mediocre for some time and, consequently, support for research was sparse. However, the faculty and the university appeared to be better than was indicated by the institutional ranking in research. In particular, KU had a group of entrepreneurial research centers with faculty eager to step up the pace.

We decided to inventory our intellectual capital on the four $\mathrm{KU}$ campuses. We did this by means of a call to the Deans and Center Directors to elicit faculty proposals for research attention. This was not a formal call for financial proposals, but rather a call for feasibility of "world class" research. Forty-seven proposals were submitted and a steering committee of Deans, Directors, and others looked for "mega themes," that is, for topics that met three major criteria: at least 50 faculty working in areas that have demonstrated, peer-reviewed strength, that are also of significance to our public. The steering committee was unanimous in selecting four megathemes: information technology, human biosciences, the human condition, and environmental science \& engineering. What is "world class" research? In my opinion, a group is doing world-class research if every international meeting in their area must invite a member of that group to participate.

Next we inventoried the three research universities of Kansas: the University of Kansas, Kansas State University and Wichita State University. Partners in this process included the AAAS, KTEC (Kansas Technology Enterprise Corporation), EPSCoR, the Senator Pat Roberts Committee on Science, Technology and the Future, and KU's Merrill Advanced Studies Center. In due course, we determined four strategic initiatives in science and technology for the state:

$>$ Information Technology

$>$ Human Biosciences

$>$ Agricultural Biotechnology

$>$ Aviation

We are working at the state, regional and national levels to promote these initiatives.

\section{Arrival at Destination}

I list several means by which one can tell that an institution has arrived at a suitable research destination:

$>$ High institutional rankings

$>$ World class research areas

$>$ Cash

> Fullest utilization of university community

$>$ Value added to society 


\section{R\&D Environment in the United States}

Some background is necessary and helpful in understanding what is nationally possible.

Lester Thurow, MIT professor of management and economics, wrote the lead article in the June, 1999, Atlantic Monthly, entitled "Building Wealth: The New Rules for Individuals, Companies and Nations." Thurow writes, "A successful knowledge-based economy requires large public investments in education, infrastructure, and research and development." He quotes rates of return on R\&D as: $24 \%$ for private rates, $66 \%$ for public rates. In the "public" rates of return, benefits accrue to the whole society. "Put simply," Thurow continues, "the payoff from social investment in basic research is as clear as anything is ever going to be in economics."

Some sound bites:

$50 \%$ of economic progress since World War II is due to technology. This includes the fact that almost 3/4 of patents issued depend at least in part on publicly funded research.

With regard to information technology, Alan Greenspan has stated that the "unexpected leap in technology is primarily responsible for the nation's phenomenal economic performance."

The $\$ 300$ billion Internet economy currently employs 1.2 million people.

> President's Information Technology Advisory Council report:

- $1 / 3$ of USA economic growth

- $1 / 3$ of all corporate R \& D

- $55 \%$ of all venture capital

- New startup every hour

- 7.4 million jobs at salaries that are $80 \%$ higher than average

My own scientific career in Numerical Analysis and then Computer Aided Geometric Design causes me to think that information technology advances during the next few years will dwarf what has come before, in terms of ubiquitous computing and visualization possibilities. These advances will include such visionary topics as molecular level, fault tolerant computer architectures that resemble biological systems, as well as advances in brain imaging and gene therapy due to virtual reality and computational power. For an institution to become a research leader, it 
must possess leadership that can utilize national trends such as these on the local level.

\section{State Rationale for Research}

Research universities provide unique cultural and economic advantages to society in general and to local communities in particular. Cultural opportunities include the advantages of a liberal education and all its corollaries. Economic impacts include the value added by the degrees to the graduates, as well as the economic ripple effect due to R\&D dollars.

Graduates are the largest form of technology transfer from research universities. We have quantified the economic impact for our state: the annual income of the alumni of our three research universities who currently reside in Kansas is $\$ 9$ billion annually. About $1 / 3$ of this total, or $\$ 3$ billion, is due to the increased salaries that our alumni earn because of their academic degrees. State taxes paid by these graduates is $\$ 700$ million annually, a figure that exceeds the annual state appropriation of $\$ 400$ million to the three universities.

We have built upon NSF methodology to create R\&D numbers for the three Kansas research universities. The annually reported "NSF numbers" comprise research expenditures in science and engineering only. Our "enhanced NSF numbers" include expenditures in non-science and engineering fields and also in training projects for all fields. The U.S. Department of Commerce estimates that, in Kansas, \$1 million in R\&D provides 40.6 jobs. The three Kansas research universities had $\$ 236.5$ million in "enhanced NSF" R\&D expenditures in fiscal year 97, which implies that almost $10,000(9,600)$ jobs are due to this source of funding. Moreover, the average salary in these jobs exceeds the average salary in our state.

\section{A Poll of the Public}

Everyone knows that the National Institutes of Health have received significant appropriations in recent years. An organization entitled Research!America has made many of the persuasive arguments that have promoted the NIH's budget. A few months ago I met with Mary Woolley, president of Research!America, and learned that they do state surveys and want to move beyond their original focus on biomedical science to the support of science in general. Kansas is an attractive state to Research!America because of the recent decisions centered on evolution. In February of this year, I called together my counterparts from Kansas State University, Wichita State University, and the Kansas Technology Enterprise Corporation (KTEC) to meet Mary Woolley. We decided to initiate a poll of the Kansas citizenry. At last week's meeting of his 
statewide Committee on Science, Technology and the Future, we spoke with Kansas Senator Pat Roberts about this project. He expressed interest in this statewide survey, and assigned Keith Yehle, a member of his Washington staff, to work with us on disseminating the results of the poll.

\section{A Tipping Point}

Malcolm Gladwell's book, The Tipping Point, demonstrates by examples how changes by relatively few people can have a large impact. There are three rules for a tipping point: the Law of the Few, the Stickiness Factor, and the Power of Context. My considerable oversimplification of the book is the following:

The Law of the Few: The example of Paul Revere illustrates that some people have exactly the right connections for making a significant impact, whereas others in the same situation cannot because they do not have these resources.

The Stickiness Factor: Successful projects frequently have some feature, say, a snappy title or phrase, which makes people remember them favorably. The image "sticks" in their mind. My own advocacy example is "Selling the Endless Frontier." This echoes "Science, the Endless Frontier" from Vannevar Bush's letter to President Franklin Roosevelt encouraging federal support of research after World War II.

The Power of Context: "Environmental tipping points are things that we can change." Gladwell gives the example of fixing up a small portion of a run-down neighborhood. By this example, the neighborhood as a whole improves itself. My example would be the indifference of a legislature to university research.

\section{Black Elk, Oglala Sioux}

In the research arena, change is a necessity. Sometimes, especially in a millennial year, it is tempting to think that we have invented everything. I am always brought back to Earth when I turn to this late nineteenth-century saying by Black Elk, an Oglala Sioux elder:

"Little else but weather ever happened in that countryVother than the sun and moon and stars going overDand there was little for the old men to do but wait for yesterday."

Let us not be like Black Elk's "old men." Rather, let us embrace change and use it to advance science and society in the $21^{\text {st }}$ century. 


\section{References}

Bush, Vannevar (1945). Science - The Endless Frontier. National Science Foundation.

Geiger, Roger (1993). Research and Relevant Knowledge: American Research Universities since World War II. Oxford University Press.

Gladwell, Malcolm (2000). The Tipping Point: How Little Things Can Make a Big Difference. Little, Brown and Company.

Graham, Hugh Davis \& Diamond, Nancy (1997). The Rise of American Research Universities: Elites and Challengers in the Postwar Era. Johns Hopkins University Press.

Grove, Andrew S. (1996). Only the Paranoid Survive: How to Exploit the Crisis Points that Challenge Every Company and Career. Doubleday Publishing Company.

Hamel, Gary \& Prahalad, C.K. (1994). Competing for the Future. Harvard Business School Press.

Stokes, Donald E. (1997). Pasteur's Quadrant: Basic Science and Technological Innovation. Brookings Institution Press.

Teich, Albert H. (Ed.) (1996). Competitiveness in Academic Research. American Association for the Advancement of Science.

Thurow, Lester (June 1999). Building Wealth: the New Rules for Individuals, Companies, and Nations. Atlantic Monthly. 